\title{
Pengaruh Jenis Dedak dan Turunan Benih terhadap Pertumbuhan dan Hasil Jamur Tiram Merah (Pleurotus flabellatus)
}

\author{
NI PUTU EKA APRIASTUTI ${ }^{1 *}$, GEDE WIJANA ${ }^{1}$, DAN I WAYAN DIARA ${ }^{2}$ \\ ${ }^{1}$ Program Studi Magister Pertanian Lahan Kering Fakultas Pertanian Universitas Udayana \\ Jl. PB. Sudirman, Denpasar, 80231, Bali \\ ${ }^{2}$ Program Studi Magister Ilmu Lingkungan Pascasarjana Universitas Udayana \\ Jl. PB. Sudirman, Denpasar, 80231, Bali \\ ${ }^{*}$ E-mail: eka_apri11@yahoo.co.id
}

\begin{abstract}
ABSTRAK
The Effect of Bran Type and Seed Derivatives on The Growth and Yield of Red Oyster Mushroom (Pleurotus flabellatus). Jenis dedak dan turunan benih merupakan faktor yang berperan terhadap pertumbuhan dan hasil jamur tiram merah (Pleurotus flabellatus). Jamur tiram dapat tumbuh alami atau dapat memanfaatkan media tanam serbuk kayu yang disebut baglog. Tujuan penelitian ini untuk menemukan jenis dedak, turunan benih dan kombinasi yang terbaik terhadap pertumbuhan dan hasil jamur tiram merah. Perlakuan terdiri atas dua faktor yang didesain dengan rancangan acak kelompok (RAK). Faktor pertama adalah jenis dedak yang terdiri atas dedak beras putih, dedak beras merah dan dedak gandum. Faktor kedua adalah turunan benih yang terdiri atas benih F2, benih F3 dan benih F4, semua perlakuan diulang lima kali. Hasil penelitian menunjukkan adanya pengaruh interaksi antara perlakuan jenis dedak dan turunan benih pada setiap variabel yang diamati, kecuali pada panjang tangkai tudung pada panen kedua dan keempat, diameter tudung pada panen pertama dan keempat. Jenis dedak beras merah dan turunan benih F2 menghasilkan berat segar jamur per baglog setiap panen tertinggi dari panen 1, 2, 3 dan 4 masing-masing yaitu 66,59 g, 64,77 g, 50,30 g dan 36,34 g. Jenis dedak beras merah dan turunan benih F2 memberikan hasil total panen berat segar jamur per baglog tertinggi yaitu $217,99 \mathrm{~g}$.
\end{abstract}

Keywords: Media, turunan benih, hasil

\section{PENDAHULUAN}

Jamur tiram (Pleurotus ostreatus) merupakan jenis jamur yang dapat tumbuh secara alami pada batang pohon yang telah mengalami pelapukan. Seiring dengan perkembangan zaman jamur tiram dibudidayakan menggunakan baglog yang memanfaatkan media tanam dari serbuk kayu gergaji, jerami, ampas tebu dan alangalang (Zubaidah et al., 2017). Jamur tiram 


\section{NI PUTU EKA APRIASTUTI et al. Pengaruh Jenis Dedak dan Turunan Benih...}

dapat tumbuh di lahan kering dengan memperhatikan suhu dan kelembapan di rumah kumbung.

Jamur tiram memiliki kandungan gizi yang lebih tinggi dibandingkan dengan jenis jamur kayu lainnya. Kandungan gizi per 100 gram jamur tiram yaitu 58\% karbohidrat, 9,3\% abu, 11,5\% serat, 1,164,80 $\mathrm{mg}$ thiamin, 4,7-4,9 $\mathrm{mg}$ riboflavin dan 46-108,7 mg niacin, kalori (energi) 265 kalori dan 18 macam asam amino (Simatupang et al., 2012). Satu baglog jamur tiram akan menghasilkan $30-35 \%$ dari berat baglog. Penambahan nutrisi pada media sangat diperlukan dalam budidaya mengingat keterbatasan nutrisi yang dikandung oleh serbuk kayu. Nutrisi yang dibutuhkan seperti nitrogen, fosfor, belerang, karbon serta beberapa unsur yang lain terdapat pada serbuk kayu dalam jumlah yang terbatas sehingga diperlukan penambahan nutrisi yang bisa didapatkan dari dedak dimana dedak mengandung protein, lemak, abu, serat, karbohidrat dan kalori (Rochman, 2015).

Benih merupakan faktor yang sangat menentukan dalam proses budidaya jamur tiram. Pembuatan benih memerlukan ketelitian tinggi karena harus dilakukan dengan keadaan steril menggunakan bahan, peralatan khusus dan komposisi media yang tepat sehingga menghasilkan jamur tiram yang berkualitas tinggi (Susilawati et al., 2016). Benih F1 diturunkan menjadi benih F2 dan benih F2 diturunkan menjadi benih F3 begitu seterusnya, selanjutnya benih hasil turunan di tanam ke media baglog. Penelitian ini sangat penting dilakukan dengan tujuan untuk menemukan pengaruh jenis dedak, turunan benih dan interaksi antara jenis dedak dan turunan benih yang terbaik terhadap pertumbuhan dan hasil jamur tiram merah.

\section{BAHAN DAN METODE}

Penelitian ini dilaksanakan di Unit Pelaksana Teknis Daerah (UPTD) Balai Benih Induk Tanaman Pangan dan Hortikultura, Dinas Pertanian dan Ketahanan Pangan Provinsi Bali. Lokasi ini terletak di Dusun Belah, Desa Luwus, Kecamatan Baturiti, Kabupaten Tabanan dari bulan Mei sampai dengan Oktober 2019.

Bahan-bahan yang digunakan dalam penelitian ini adalah serbuk gergaji, dedak, dolomit, gula pasir, tepung terigu, kapas, kantong plastik, alkohol, spiritus, benih F2, F3, F4 jamur dan air bersih. Alat-alat yang digunakan adalah masker, spatula, pinset, cincin baglog, lampu spiritus, sekop, keranjang pengangkut/krat plastik, alat 
sterilisasi, pemadat baglog, laminar air flow dan timbangan elektrik.

Perlakuan terdiri atas dua faktor yang didesain dengan rancangan acak kelompok (RAK) faktorial. Faktor pertama adalah jenis dedak yang terdiri atas dedak beras putih (D1), dedak beras merah (D2) dan dedak gandum (D3) sedangkan faktor kedua adalah turunan benih jamur tiram yang terdiri atas benih F2 (B1), benih F3 (B2) dan benih F4 (B3) sehingga terdapat 9 perlakuan kombinasi yang diulang lima kali. Pada setiap perlakuan terdiri atas 5 baglog jamur sehingga jumlah baglog seluruhnya adalah 225 baglog.

Tahapan-tahapan pelaksanaan percobaan adalah sebagai berikut:

Pembuatan media

1. Perendaman dan penirisan serbuk kayu

Pembuatan media diawali dengan perendaman serbuk kayu. Serbuk kayu yang digunakan sebagai media adalah serbuk kayu sengon (Albazia falcataria). Perendaman dilakukan selama dua hari. Setelah perendaman selesai selanjutnya dilakukan penirisan agar air yang berlebihan dalam serbuk kayu tersebut cepat menetes.

2. Pengayakan serbuk kayu
Media serbuk kayu yang kurang homogen perlu dilakukan pengayakan sebanyak satu kali untuk memisahkan ukuran serbuk kayu yang kurang seragam. Ukuran serbuk kayu yang digunakan $\pm 0,84$ $\mathrm{mm}-1 \mathrm{~mm}$.

\section{Pencampuran media}

Bahan-bahan yang dibutuhkan adalah serbuk kayu, dedak (dedak beras putih varietas Ciherang, dedak beras merah varietas Inpari 24 dan dedak gandum) 20\% dari serbuk kayu, dolomit 6-8\% dari serbuk kayu, tepung terigu 0,5\% dari serbuk kayu, gula $0,2 \%$ dari serbuk kayu (5 kg serbuk kayu, $1 \mathrm{~kg}$ dedak, 0,3 kg dolomit, 0,025 kg tepung terigu dan $0,01 \mathrm{~kg}$ gula). Bahan yang sudah ditimbang sesuai dengan kebutuhannya dicampur secara merata dengan kadar air $50-65 \%$ dan $\mathrm{pH}$ netral antara $6-7$.

4. Pembungkusan media

Campuran media dimasukkan ke dalam plastik polypropylene (PP) dengan ukuran $0,05 \times 18 / 9 \times 33 \mathrm{~cm}$ (tebal x lebar x panjang), kemudian dipadatkan dan dilubangi dengan berat media $1 \mathrm{~kg}$ per plastik. Selanjutnya bagian ujung plastik yang terbuka, tepat di atas batas media tanam dipasang cincin dan diisi/disumbat dengan kapas. 


\section{NI PUTU EKA APRIASTUTI et al. Pengaruh Jenis Dedak dan Turunan Benih...}

\section{Sterilisasi media}

Media baglog yang sudah selesai melalui proses pembungkusan, dimasukkan ke alat sterilisasi. Sterilisasi dilakukan pada suhu $80-90^{\circ} \mathrm{C}$ selama $6-8$ jam. Sterilisasi menggunakan alat sterilisasi yang sudah dimodifikasi, kemudian alat steril dipanaskan sampai air di bagian bawah ram mendidih. Uap panas yang bertekanan tinggi dari air rebusan inilah yang mensterilkan tumpukan baglog di atasnya.

6. Pendinginan media

Media baglog yang telah disterilisasi didinginkan selama 12 jam sebelum dilakukan inokulasi. Pendinginan dilakukan sampai suhunya mencapai $25-35^{\circ} \mathrm{C}$.

Penanaman benih segera dilakukan setelah media baglog sudah dingin dan dilakukan di ruangan inokulasi yang tempatnya harus steril. Alat inokulasi disterilisasi terlebih dahulu dengan menggunakan alkohol $70 \%$ dan lampu spiritus (lampu bunsen). Inokulasi dilakukan dengan membuka satu per satu penutup kapas media baglog selanjutnya benih F2 yang merupakan turunan dari benih F1 yang berasal dari media PDA (potatoes dextrosa agar), kemudian ditanami bagian dari badan buah jamur tiram, benih F3 turunan dari benih F2 dan benih F4 merupakan turunan dari benih F3 selanjutnya dituangkan di tengah-tengah lubang tanam media baglog dan tutup kembali baglog dengan penutupnya.

Inkubasi atau proses penumbuhan miselium dilakukan dengan cara menyimpan baglog yang ditata rebah di atas rak dengan suhu $25-30^{\circ} \mathrm{C}$, kelembapan $65-70 \%$ yang diukur dengan alat higrometer dan baglog disimpan di ruang gelap selama \pm 40 hari sampai media baglog dipenuhi miselium berwarna putih merata. Selanjutnya baglog dimasukkan ke dalam kumbung.

Tubuh buah jamur tumbuh optimal pada suhu $18-20^{\circ} \mathrm{C}$ dengan kelembapan udara $80-85 \%$. Untuk menjaga kelembapan dan suhu optimal dilakukan dengan penyiraman $2-3$ kali sehari menggunakan hand sprayer. Penumbuhan dilakukan dengan menoreh plastik baglog pada bagian atas $\pm 1 \mathrm{~cm}$. Penorehan dapat satu atau dua tempat dengan menggunakan pisau scalpel atau pisau cutter steril. Di tempat torehan tadi tubuh buah akan tumbuh setelah 7 - 10 hari hingga mencapai pertumbuhan optimal dan siap panen. Penorehan kemudian dilakukan pada bagian lain baglog untuk pemerataan pemanfaatan nutrisi pada media baglog. 
Panen dilakukan secara manual yaitu mencabut jamur beserta akarnya. Panen dilakukan pada umur 4 hari sejak pembentukan calon tubuh buah. Masa panen mencapai 2 bulan dengan interval pemanenan antara $1-2$ minggu per baglog.

Pengamatan dilakukan mulai saat penanaman benih F2, F3 dan F4 di ruang inokulasi sampai panen ke 4. Variabel yang diamati dalam penelitian ini adalah saat miselium tumbuh penuh (hari setelah tanam/hst), saat munculnya badan buah pertama (hari setelah masuk kumbung/hsmk), panjang tangkai tudung $(\mathrm{cm})$, diameter tangkai tudung $(\mathrm{cm})$, diameter tudung $(\mathrm{cm})$, jumlah tangkai dan jumlah tudung buah jamur (buah), berat segar jamur per baglog setiap panen dan hasil total panen berat segar jamur per baglog (g) dan keserempakan waktu panen baglog jamur (hari).

Data yang dikumpulkan dianalisis menggunakan analisis varian (sidik ragam) sesuai dengan rancangan yang dipergunakan. Apabila dalam daftar sidik ragam menunjukkan pengaruh nyata atau sangat nyata maka menggunakan uji Duncan's dengan taraf 5\% (Gomez dan Gomez, 1995).

\section{HASIL DAN PEMBAHASAN}

Perlakuan jenis dedak (D) dan turunan benih jamur tiram merah (B) menunjukkan pengaruh interaksi sangat nyata $(\mathrm{P}<0,01)$ dan nyata $(\mathrm{P}<0,05)$ terhadap semua variabel yang diamati (Tabel 1).

Tabel 1. Signifikansi pengaruh jenis dedak (D) dan turunan benih jamur tiram merah (B) terhadap semua variabel yang diamati

\begin{tabular}{|c|c|c|c|c|}
\hline \multirow{2}{*}{ No } & \multirow{2}{*}{ Variabel } & \multicolumn{3}{|c|}{ Perlakuan } \\
\hline & & $\mathrm{D}$ & $\mathrm{B}$ & DB \\
\hline 1. & Saat miselium tumbuh penuh (hst) & $* *$ & $* *$ & $*$ \\
\hline 2. & Saat munculnya badan buah pertama (hsmk) & $* *$ & $*$ & $* *$ \\
\hline 3. & Panjang tangkai tudung $(\mathrm{cm})$ & $*$ & ns & $*$ \\
\hline 4. & Diameter tangkai tudung $(\mathrm{cm})$ & $* *$ & $* *$ & $* *$ \\
\hline 5. & Diameter tudung $(\mathrm{cm})$ & ns & ns & $* *$ \\
\hline 6. & Jumlah tangkai dan jumlah tudung buah jamur (buah) & $* *$ & * & $*$ \\
\hline \multirow[t]{5}{*}{7.} & Berat segar jamur per baglog setiap panen $(\mathrm{g})$ & & & \\
\hline & - Panen 1 & $* *$ & $*$ & $* *$ \\
\hline & - Panen 2 & $* *$ & $* *$ & $* *$ \\
\hline & - Panen 3 & $* *$ & $* *$ & $* *$ \\
\hline & - Panen 4 & $* *$ & $* *$ & $* *$ \\
\hline 8. & Hasil total panen berat segar jamur per baglog (g) & $* *$ & $* *$ & $* *$ \\
\hline 9. & Keserempakan waktu panen baglog jamur (hari) & ** & $* *$ & $* *$ \\
\hline
\end{tabular}

\section{Keterangan :}

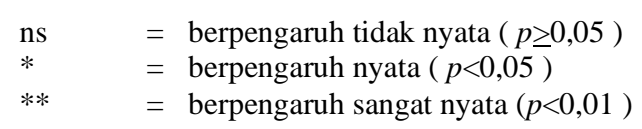




\section{NI PUTU EKA APRIASTUTI et al. Pengaruh Jenis Dedak dan Turunan Benih...}

Saat miselium tumbuh tercepat, yaitu 30,44 hst dihasilkan dari perlakuan benih F4 yang tumbuh pada media mengandung dedak beras putih, sedangkan perlakuan jenis dedak gandum dan benih F2
(D3B1) menghasilkan saat miselium tumbuh penuh paling lambat yaitu 40,16 hst (Tabel 2).

Tabel 2. Pengaruh jenis dedak (D) dan turunan benih jamur tiram merah (B) terhadap saat miselium tumbuh penuh (hst)

\begin{tabular}{lccc}
\hline \multirow{2}{*}{ Perlakuan } & \multicolumn{3}{c}{ Turunan benih jamur tiram merah } \\
\cline { 2 - 4 } & Benih F2 (B1) & Benih F3 (B2) & Benih F4 (B3) \\
\hline Jenis dedak & $32,88 \mathrm{~b}$ & $32,48 \mathrm{~b}$ & $30,44 \mathrm{c}$ \\
Dedak beras putih (D1) & $33,84 \mathrm{~b}$ & $32,92 \mathrm{~b}$ & $33,16 \mathrm{~b}$ \\
Dedak beras merah (D2) & $40,16 \mathrm{a}$ & $39,28 \mathrm{a}$ & $39,92 \mathrm{a}$ \\
Dedak gandum (D3) & & &
\end{tabular}

Keterangan: Angka-angka yang diikuti oleh huruf yang sama adalah tidak berbeda nyata pada uji jarak berganda Duncan 5\%.

Perlakuan jenis dedak gandum dan menghasilkan saat munculnya badan buah benih F2 (D3B1) menghasilkan saat pertama paling lambat yaitu 9,40 hsmk munculnya badan buah pertama tercepat (Tabel 3).

yaitu 6,64 hsmk sedangkan jenis dedak

gandum dan benih F4 (D3B3)

Tabel 3. Pengaruh jenis dedak (D) dan turunan benih jamur tiram merah (B) terhadap saat munculnya badan buah pertama (hsmk)

\begin{tabular}{lccc}
\hline \multirow{2}{*}{ Perlakuan } & \multicolumn{3}{c}{ Turunan benih jamur tiram merah } \\
\cline { 2 - 4 } & Benih F2 (B1) & Benih F3 (B2) & Benih F4 (B3) \\
\hline Jenis dedak & $8,52 \mathrm{a}$ & $8,24 \mathrm{~b}$ & $7,48 \mathrm{~d}$ \\
Dedak beras putih (D1) & $8,80 \mathrm{a}$ & $8,70 \mathrm{a}$ & $8,84 \mathrm{a}$ \\
Dedak beras merah (D2) & $6,64 \mathrm{e}$ & $7,64 \mathrm{c}$ & $9,40 \mathrm{a}$ \\
Dedak gandum (D3) &
\end{tabular}

$\overline{\text { Keterangan: Angka-angka yang diikuti oleh huruf yang sama adalah tidak berbeda nyata pada uji jarak }}$ berganda Duncan 5\%. 
Perlakuan jenis dedak beras putih pada jenis dedak gandum dan benih F3 dan benih F2 (D1B1) menghasilkan (D3B2) yaitu 2,84 cm (Tabel 4). panjang tangkai tudung terpanjang yaitu $3,59 \mathrm{~cm}$ sedangkan yang paling pendek

Tabel 4. Pengaruh jenis dedak (D) dan turunan benih jamur tiram merah (B) terhadap panjang tangkai tudung $(\mathrm{cm})$

\begin{tabular}{lccc}
\hline \multirow{2}{*}{ Perlakuan } & \multicolumn{3}{c}{ Turunan benih jamur tiram merah } \\
\cline { 2 - 4 } & Benih F2 (B1) & Benih F3 (B2) & Benih F4 (B3) \\
\hline Jenis dedak & $3,59 \mathrm{a}$ & $3,42 \mathrm{a}$ & $3,13 \mathrm{a}$ \\
Dedak beras putih (D1) & $2,95 \mathrm{~b}$ & $3,50 \mathrm{a}$ & $2,86 \mathrm{c}$ \\
Dedak beras merah (D2) & $3,09 \mathrm{a}$ & $2,84 \mathrm{c}$ & $3,14 \mathrm{a}$ \\
Dedak gandum (D3) & & &
\end{tabular}

Keterangan: Angka-angka yang diikuti oleh huruf yang sama adalah tidak berbeda nyata pada uji jarak berganda Duncan 5\%.

Perlakuan jenis dedak beras merah cm sedangkan yang paling rendah pada dan benih F2 (D2B1) menghasilkan jenis dedak gandum dan benih F3 (D3B2) diameter tangkai tudung tertinggi yaitu 1,79 yaitu $0,94 \mathrm{~cm}$ (Tabel 5).

Tabel 5. Pengaruh jenis dedak (D) dan turunan benih jamur tiram merah (B) terhadap diameter tangkai tudung $(\mathrm{cm})$

\begin{tabular}{lrcc}
\hline \multicolumn{1}{c}{ Perlakuan } & \multicolumn{3}{c}{ Turunan benih jamur tiram merah } \\
\cline { 2 - 4 } & Benih F2 (B1) & Benih F3 (B2) & Benih F4 (B3) \\
\hline Jenis dedak & $1,08 \mathrm{e}$ & $1,40 \mathrm{c}$ & $1,39 \mathrm{c}$ \\
Dedak beras putih (D1) & $1,79 \mathrm{a}$ & $1,54 \mathrm{~b}$ & $1,67 \mathrm{a}$ \\
Dedak beras merah (D2) & $1,13 \mathrm{e}$ & $0,94 \mathrm{f}$ & $1,23 \mathrm{~d}$ \\
Dedak gandum (D3) & &
\end{tabular}

Keterangan: Angka-angka yang diikuti oleh huruf yang sama adalah tidak berbeda nyata pada uji jarak berganda Duncan 5\%.

Perlakuan jenis dedak gandum dan yang paling rendah pada jenis dedak benih F2 (D3B1) menghasilkan diameter gandum dan benih F3 (D3B2) yaitu 5,80 tudung tertinggi yaitu $6,48 \mathrm{~cm}$ sedangkan $\mathrm{cm}$ (Tabel 6). 


\section{NI PUTU EKA APRIASTUTI et al. Pengaruh Jenis Dedak dan Turunan Benih...}

Tabel 6. Pengaruh jenis dedak (D) dan turunan benih jamur tiram merah (B) terhadap diameter tudung $(\mathrm{cm})$

\begin{tabular}{|c|c|c|c|}
\hline \multirow[t]{2}{*}{ Perlakuan } & \multicolumn{3}{|c|}{ Turunan benih jamur tiram merah } \\
\hline & Benih F2 (B1) & Benih F3 (B2) & Benih F4 (B3) \\
\hline \multicolumn{4}{|l|}{ Jenis dedak } \\
\hline Dedak beras putih (D1) & $5,85 \mathrm{c}$ & $6,08 \mathrm{a}$ & $5,93 \mathrm{c}$ \\
\hline Dedak beras merah (D2) & $5,85 \mathrm{c}$ & $6,36 \mathrm{a}$ & $5,95 \mathrm{~b}$ \\
\hline Dedak gandum (D3) & $6,48 \mathrm{a}$ & $5,80 \mathrm{c}$ & $6,02 \mathrm{~b}$ \\
\hline
\end{tabular}

Keterangan: Angka-angka yang diikuti oleh huruf yang sama adalah tidak berbeda nyata pada uji jarak berganda Duncan 5\%.

Perlakuan jenis dedak gandum dan benih F3 (D3B2) menghasilkan jumlah tangkai dan jumlah tudung buah jamur tertinggi yaitu 7,68 buah sedangkan yang paling rendah pada jenis dedak beras putih dan benih F3 (D1B2) yaitu 6,44 buah (Tabel 7).

Tabel 7. Pengaruh jenis dedak (D) dan turunan benih jamur tiram merah (B) terhadap jumlah tangkai dan jumlah tudung buah jamur (buah)

\begin{tabular}{lrcc}
\hline \multirow{2}{*}{ Perlakuan } & \multicolumn{3}{c}{ Turunan benih jamur tiram merah } \\
\cline { 2 - 4 } & Benih F2 (B1) & Benih F3 (B2) & Benih F4 (B3) \\
\hline Jenis dedak & $6,60 \mathrm{c}$ & $6,44 \mathrm{e}$ & $6,90 \mathrm{~b}$ \\
Dedak beras putih (D1) & $6,88 \mathrm{~b}$ & $6,48 \mathrm{~d}$ & $6,92 \mathrm{~b}$ \\
Dedak beras merah (D2) & $7,24 \mathrm{~b}$ & $7,68 \mathrm{a}$ & $7,64 \mathrm{a}$ \\
Dedak gandum (D3) & &
\end{tabular}

Keterangan: Angka-angka yang diikuti oleh huruf yang sama adalah tidak berbeda nyata pada uji jarak berganda Duncan 5\%.

Perlakuan jenis dedak beras merah dan benih F2 (D2B1) mulai panen pertama sampai keempat menghasilkan berat segar jamur per baglog setiap panen tertinggi berturut-turut yaitu $66,59 \mathrm{~g}, 64,77 \mathrm{~g}, 50,30$ $\mathrm{g}$ dan 36,34 g sedangkan yang paling rendah pada panen pertama dan panen ketiga menunjukkan bahwa jenis dedak gandum dan benih F3 (D3B2) yaitu 47,84 g dan 30,88 g, panen kedua dan panen keempat menunjukkan bahwa jenis dedak gandum dan benih F2 (D3B1) memiliki berat segar jamur per baglog setiap panen paling rendah yaitu 37,25 g dan $22 \mathrm{~g}$ (Tabel 8). Perlakuan jenis dedak beras merah dan benih F2 (D2B1) menghasilkan hasil total panen berat segar jamur per baglog tertinggi yaitu 217,99 g sedangkan yang paling rendah pada jenis dedak gandum dan benih F3 (D3B2) yaitu 142,96 g (Tabel 9). 
Tabel 8. Pengaruh jenis dedak (D) dan turunan benih jamur tiram merah (B) terhadap berat segar jamur per baglog setiap panen $(\mathrm{g})$

\begin{tabular}{|c|c|c|c|}
\hline \multirow[t]{2}{*}{ Perlakuan } & \multicolumn{3}{|c|}{ Turunan benih jamur tiram merah } \\
\hline & Benih F2 (B1) & Benih F3 (B2) & Benih F4 (B3) \\
\hline \multicolumn{4}{|l|}{ Jenis dedak } \\
\hline \multicolumn{4}{|l|}{ Panen 1} \\
\hline Dedak beras putih (D1) & $57,25 \mathrm{c}$ & $61,79 \mathrm{~b}$ & $61,95 \mathrm{~b}$ \\
\hline Dedak beras merah (D2) & 66,59 a & $59,56 \mathrm{~b}$ & $62,48 b$ \\
\hline Dedak gandum (D3) & $53,25 \mathrm{~d}$ & $47,84 \mathrm{f}$ & $50,70 \mathrm{e}$ \\
\hline \multicolumn{4}{|l|}{ Panen 2} \\
\hline Dedak beras putih (D1) & $51,12 \mathrm{c}$ & $61,39 \mathrm{a}$ & $53,50 \mathrm{c}$ \\
\hline Dedak beras merah (D2) & $64,77 \mathrm{a}$ & $59,19 \mathrm{~b}$ & $50,15 \mathrm{c}$ \\
\hline Dedak gandum (D3) & $37,25 \mathrm{~d}$ & $37,80 \mathrm{~d}$ & $40,06 \mathrm{~d}$ \\
\hline \multicolumn{4}{|l|}{ Panen 3} \\
\hline Dedak beras putih (D1) & $47,21 \mathrm{~b}$ & $46,87 \mathrm{c}$ & $47,37 \mathrm{~b}$ \\
\hline Dedak beras merah (D2) & $50,30 \mathrm{a}$ & $49,77 \mathrm{a}$ & $47,44 \mathrm{~b}$ \\
\hline Dedak gandum (D3) & $36,93 \mathrm{~d}$ & $30,88 \mathrm{e}$ & $32,71 \mathrm{e}$ \\
\hline \multicolumn{4}{|l|}{ Panen 4} \\
\hline Dedak beras putih (D1) & $34,22 \mathrm{a}$ & $34,57 \mathrm{a}$ & $30,70 \mathrm{~b}$ \\
\hline Dedak beras merah (D2) & $36,34 \mathrm{a}$ & 36,26 a & $30,34 \mathrm{~b}$ \\
\hline Dedak gandum (D3) & $22,00 \mathrm{~d}$ & $26,44 \mathrm{c}$ & $24,64 \mathrm{c}$ \\
\hline
\end{tabular}

Keterangan: Angka-angka yang diikuti oleh huruf yang sama pada masing-masing tahapan panen adalah tidak berbeda nyata pada uji jarak berganda Duncan $5 \%$.

Tabel 9. Pengaruh jenis dedak (D) dan benih jamur tiram merah (B) terhadap hasil total panen berat segar jamur per baglog $(\mathrm{g})$

\begin{tabular}{lrcc}
\hline \multicolumn{1}{c}{ Perlakuan } & \multicolumn{3}{c}{ Benih jamur tiram merah } \\
\cline { 2 - 4 } & Benih F2 (B1) & Benih F3 (B2) & Benih F4 (B3) \\
\hline Jenis dedak & & & \\
Dedak beras putih (D1) & $189,80 \mathrm{c}$ & $204,62 \mathrm{~b}$ & $193,52 \mathrm{c}$ \\
Dedak beras merah (D2) & $217,99 \mathrm{a}$ & $204,78 \mathrm{~b}$ & $190,41 \mathrm{c}$ \\
Dedak gandum (D3) & $149,43 \mathrm{~d}$ & $142,96 \mathrm{~d}$ & $148,10 \mathrm{~d}$ \\
\hline
\end{tabular}

Keterangan: Angka-angka yang diikuti oleh huruf yang sama adalah tidak berbeda nyata pada uji jarak berganda Duncan 5\%.

Keserempakan waktu panen baglog yang paling memenuhi standar serempak perlakuan D1B2, D2B1 dan D2B3 yaitu
1,57 hari, 1,63 hari dan 1,72 hari sedangkan perlakuan yang lain memenuhi standar cukup serempak (Tabel 10). 


\section{NI PUTU EKA APRIASTUTI et al. Pengaruh Jenis Dedak dan Turunan Benih...}

Tabel 10. Pengaruh jenis dedak (D) dan benih jamur tiram merah (B) terhadap keserempakan waktu panen baglog (hari)

\begin{tabular}{lccc}
\hline \multicolumn{1}{c}{ Perlakuan } & \multicolumn{3}{c}{ Benih jamur tiram merah } \\
\cline { 2 - 4 } & Benih F2 (B1) & Benih F3 (B2) & Benih F4 (B3) \\
\hline Jenis dedak & & & \\
Dedak beras putih (D1) & $2,25 \mathrm{a}$ & $1,57 \mathrm{~b}$ & $2,32 \mathrm{a}$ \\
Dedak beras merah (D2) & $1,63 \mathrm{a}$ & $2,20 \mathrm{a}$ & $1,72 \mathrm{a}$ \\
Dedak gandum (D3) & $2,00 \mathrm{a}$ & $1,94 \mathrm{a}$ & $2,82 \mathrm{a}$ \\
\hline
\end{tabular}

Keterangan: Angka-angka yang diikuti oleh huruf yang sama adalah tidak berbeda nyata pada uji jarak berganda Duncan 5\%.

Tabel 2 menunjukkan saat miselium tumbuh penuh tercepat pada perlakuan jenis dedak beras putih dan benih F4 (D1B3). Nutrisi yang terpenting dibutuhkan dalam pertumbuhan miselium adalah selulosa, hemiselulosa, lignin yang terkandung dalam serbuk gergaji dan protein pada dedak (Winarni dan Rahayu, 2002). Saat munculnya badan buah pertama tercepat ditunjukkan oleh jenis dedak gandum dan benih F2 (D3B1) pada Tabel 3. Munculnya badan buah pertama sangat menentukan waktu panen buah jamur. Dedak gandum dapat menambah ketersediaan karbon yang berfungsi membangun miselium dan enzim yang dibutuhkan dalam budidaya jamur tiram begitu juga dengan penggunaan benih F2, semakin kecil nilai F maka semakin kuat miselium dan semakin cepat munculnya badan buah pertama

Panjang tangkai tudung terpanjang dihasilkan dari benih F2 yang ditanam pada media mengandung dedak beras putih dan perlakuan jenis dedak beras merah dan benih F2 (D2B1) memiliki diameter tangkai tudung tertinggi (Tabel 5). Diameter tudung tertinggi ditunjukkan oleh jenis dedak gandum dan benih F2 (Tabel 6). Perlakuan jenis dedak gandum dan benih F3 (D3B2) memiliki jumlah tangkai tudung buah jamur dan jumlah tudung buah jamur tertinggi (Tabel 7). Jamur tiram memperoleh makanan dengan cara mengeluarkan enzimenzim yang dapat merubah kompunen selulosa, hemiselulosa dan lignin menjadi gula sederhana yang digunakan untuk pembentukan badan buah (Simatupang et al., 2012).

Berat segar jamur per baglog setiap panen akan mempengaruhi hasil total panen per baglog. Perlakuan jenis dedak beras merah dan benih F2 (D2B1) mulai panen pertama sampai keempat memiliki berat segar jamur per baglog setiap panen tertinggi (Tabel 8). Tabel 9 menunjukkan hasil total panen berat segar jamur per 
baglog tertinggi pada perlakuan dedak beras merah dan benih F2 (D2B1) hal ini disebabkan penggunaan serbuk kayu yang mengandung $46,62 \%$ cellulose, $29,10 \%$ lignin, dedak beras merah yang mengandung $17,2 \%$ protein, $50,7 \%$ karbohidrat, $0,21 \%$ vitamin $\mathrm{B} 1$ dan penggunaan benih F2 bisa dimanfaatkan secara sempurna mulai dari panen pertama sampai keempat sehingga hasil jamur tiram didapat secara optimal. Dari hasil penelitian ini benih F2 lebih bagus dibandingkan benih F3 dan benih F4.

Keserempakan waktu panen baglog yang paling memenuhi standar serempak adalah perlakuan D1B2, D2B1 dan D2B3 sedangkan perlakuan yang lain memenuhi standar cukup serempak (Tabel 10). Semakin serempak munculnya badan buah jamur maka semakin serempak pada saat panen. Kriteria standar yang digunakan untuk menentukan keserempakan yaitu sangat serempak $( \pm \leq 1$ hari), serempak $( \pm$ $\geq 1-<2$ hari), cukup ( $\geq 2-<3$ hari), kurang serempak $(\geq 3-<4$ hari) dan sangat tidak serempak ( $\pm>4$ hari).

Berdasarkan paparan di atas maka dapat dikatakan bahwa jenis dedak beras merah dan benih F2 (D2B1) memberikan kontribusi yang sangat besar pada variabel diameter tangkai tudung dan secara keseluruhan yang terlihat jelas pada berat segar jamur per baglog setiap panen dan hasil total panen berat segar jamur per baglog.

\section{SIMPULAN}

Dari hasil penelitian ini maka dapat disimpulkan yaitu jenis dedak beras merah dan turunan benih F2 (D2B1) menunjukkan pengaruh interaksi terbaik terhadap diameter tangkai tudung, berat segar jamur per baglog setiap panen dan hasil total panen berat segar jamur per baglog. Jenis dedak beras merah dan turunan benih F2 menghasilkan berat segar jamur per baglog setiap panen tertinggi dari panen 1, 2, 3 dan 4 masing-masing yaitu 66,59 g, 64,77 g, $50,30 \mathrm{~g}$ dan $36,34 \mathrm{~g}$ dan hasil total panen berat segar jamur per baglog tertinggi yaitu $217,99 \mathrm{~g}$.

\section{DAFTAR PUSTAKA}

Gomez, K. A., \& Gomez, A. (1995). Prosedur Statistik untuk Penelitian Pertanian. Jakarta: Universitas Indonesia Press (terjemahan).

Rochman, A. (2015). Perbedaan Proporsi Dedak Dalam Media Tanam terhadap Pertumbuhan Jamur Tiram Putih (Pleurotus florida). Jurnal Agribisnis Fakultas Pertanian Unita. 11(13) : 5667.

Simatupang, E., Murniati., Saputra, S. I. (2012). Pengaruh Pemberian Beberapa Dosis Bekatul pada 
NI PUTU EKA APRIASTUTI et al. Pengaruh Jenis Dedak dan Turunan Benih...

Medium Serbuk Gergaji terhadap Pertumbuhan dan Produksi Jamur Tiram Putih (Pleurotus ostreatus). Jurnal Agroteknologi Fakultas Pertanian Universitas Riau.

Susilawati, I. O., Imaningsih, W., \& Mulyanto, A. (2016). Formulasi Media Produksi Bibit F2 Jamur Tiram Putih. Bio-site. 3(1) : 12-18.

Winarni, I., \& Rahayu, U. (2002). Pengaruh Formulasi Media Tanam dengan Bahan Dasar Serbuk Gergaji terhadap Produksi Jamur Tiram Putih (Pleurotus ostreatus). Jurnal Matematika, Sains dan Teknologi. 3(2) : 20-27.

Zubaidah, S., Saputera., \& Sartika, Y. (2013). Peningkatan Pertumbuhan dan Hasil Jamur Tiram (Pleurotus Ostreatus) Melalui Variasi Komposisi Media Tanam. Jurnal Agripeat. 14(2) : 95-102. 